\title{
Factors that promote social media marketing in retail companies
}

\section{Factores que promueven el mercadeo de redes sociales en las empresas del comercio minorista}

\author{
Diana Arango-Botero*1, Alejandro Valencia-Arias ${ }^{2}$, \\ Jonathan Bermúdez-Hernández ${ }^{1}$, Laura Duque-Cano ${ }^{3}$ \\ ${ }^{1}$ Instituto Tecnológico Metropolitano, Colombia \\ ${ }^{2}$ Corporación Universitaria Americana, Colombia \\ ${ }^{3}$ Institución Universitaria Escolme, Colombia
}

Received February 21, 2019; accepted February 4, 2020

Available online October 8, 2020

\begin{abstract}
Reaching consumers effectively is one of the main challenges facing businesses, particularly those in retail. The latter is due to advances in information technology and the phenomenon of social media has given rise to new digital and asynchronous tools to increase dialogue between businesses and consumers. This study applied the Confirmatory Factor Analysis and Structural Equations Modeling to analyze data collected from a questionnaire applied to 421 marketing managers in Medellín's retail sector (Colombia). This study uses the Technology Acceptance Model - TAM to identify the factors that promote the adoption of social media marketing in retail companies. Identifying these factors facilitates the design of strategies to take advantage of this form of marketing to retain current customers and reach potential customers. This study highlights that the usefulness of social networks does not depend on the perception of how easy or difficult it is to use them as some authors have pointed out. Furthermore, it allows reaffirming the positive influence of Trust on the Perceived Usefulness construct and Perceived Ease of Use, which promotes the adoption of marketing in Social Media.
\end{abstract}

JEL code: $\mathrm{M} 31, \mathrm{~L} 81$

Keywords: Marketing; Retail sector; Social media; Structural equations modeling, Technology acceptance model

* Corresponding author.

E-mail address: dianaarangob@itm.edu.co (D.Arango-Botero).

Peer Review under the responsibility of Universidad Nacional Autónoma de México. 


\section{Resumen}

Uno de los principales desafíos de las empresas, especialmente de aquellas que se dedican al comercio minorista, es llegar a los consumidores de una manera efectiva. Los avances de las tecnologías de la información y el fenómeno de las redes sociales han incorporado nuevas herramientas y formas de intermediación que son de interés para el mercadeo. El presente estudio aplica el análisis factorial confirmatorio y el modelo de ecuaciones estructurales para analizar 421 cuestionarios aplicados a gerentes de mercadeo del sector comercio minorista en la ciudad de Medellín (Colombia). Este estudio usa el Modelo de Aceptación Tecnológica (TAM) para identificar los factores que promueven la adopción del mercadeo de redes sociales. La identificación de estos factores facilita el diseño de estrategias para la retención de los consumidores actuales y para alcanzar a los consumidores potenciales. Dentro de los hallazgos se resalta que la utilidad de las redes sociales no depende de la percepción de que tan fácil o difícil es su uso como algunos autores han señalado en estudios previos. Además, se destaca la influencia positiva de la confianza sobre la utilidad percibida y la facilidad de uso percibida, los cuales son factores que promueven la adopción del mercadeo de redes sociales.

Código JEL: M31, L81

Palabras clave: Mercadeo; Sector de comercio minorista; Redes sociales; Modelo de ecuaciones estructurales; Modelo de aceptación tecnológica

\section{Introduction}

Consumption behaviors have changed continuously and promoted the evolution of people's habits and behaviors, which directly affects the economy and its related aspects. Such habits and behaviors have been permeated by technological advances in connectivity and accessibility to information networks. For those reasons, small- and medium-sized enterprises have focused their attention on fields such as e-commerce (Tarazana et al., 2014).

Companies that make use of electronic commerce acquire the capacity to operate widely by means of strategies that allow them to overcome geographic and market barriers in order to show their products and services. This type of commerce allows, in addition, an easier measurement of marketing and advertising strategies for companies; thus, they have more information to develop content better targeted at the specific consumers of each productive sector. A clear example in Colombia is Grupo Éxito, one of the most important companies in the retail sector in the country. Different strategies and alliances, such as electronic commer- 
ce and omnichannel (company-client communication model), have allowed the company to secure a leading position in the market, establish a good connection between the offline and online worlds, and give consumers what they need through differentiated experiences that meet their needs (Zuluaga, 2015).

Colombia represents today a great opportunity for electronic commerce because of the profile of its new consumers. The latter focus their attention on personal shopping experiences, giving importance not only to the best prices but also to other criteria that were not previously regarded as priorities. These consumers, more demanding and selective, are interested in a modern form of purchase that offers a greater variety of products. These trends are reflected in electronic commerce, new formats of apparel retail, modern drugstores, and the growth of direct sales channels.

In addition to the new consumption habits and economic growth that undoubtedly favor electronic commerce in Colombia, the policy of the national government involves the massification and appropriation of digital technologies, where the internet plays a very important role (Paiño, 2016).

Therefore, managers must implement strategies to improve information access, develop customer loyalty, open new businesses and distribution channels, and address other factors to meet consumer's needs where and when they require it. In that sense, social media has become an effective way to have closer interactions with consumers, responding to their wishes and needs in a timely and efficient manner. This enables companies to reach a privileged position among consumers, which will later produce positive effects on their performance (Silva, 2011).

It is in this context that the study focuses on analyzing social media marketing and the factors that promote its adoption by companies in the retail sector. In the literature, factors such as trust, perceived ease of use, and perceived usefulness have been identified to be related to attitudinal and behavioral variables associated with technological adoption. Identifying such factors in the context of social media marketing facilitates the design and implementation of strategies related to the use of this form of marketing. Given that the use of social media is mediated and supported by technology, the Technology Acceptance Model (TAM) will be used to identify these factors. This article is organized as follows. First, we introduce the concepts of social media marketing and social commerce. Second, we describe the Technological Acceptance Model and a theoretical basis to establish the relationships between the constructs under analysis. Third, we detail the methodology and analyze the results. Finally, we discuss the main findings and contributions of this study to the field of marketing. 


\section{Theoretical framework}

\section{Social media}

Social media have rapidly changed the focus of contemporary marketing (Dehghani \& Tumer, 2015) and have influenced brand-consumer interactions (Hamilton et al., 2016). With the support of mobile computing, the internet, cloud computing and other emerging technologies, new types of applications such as social media have increased the forms and reach of human creation and the use of information (Li et al., 2015), while also becoming more and more popular among people who are active on the internet. For example, according to figures published in Global Digital Reports, as of 2019, there are 3484 million social media users, which constitutes a 9\% increase over 2018, when 3196 million users were reported (Kemp, 2019). Social media has an effect in marketing activities on continuance, participation and purchase intentions via the mediation of social identification, perceived value and satisfaction (Shih-Chih \& Chieh-Peng, 2019). This is mainly due to users' ability to communicate in real time and asynchronously with a wide group of people of their choosing (Kumar et al., 2015). By other hand, companies should create innovative customer experiences and specific strategies for media to identify the best path for driving up social media marketing performance and have a better connection with the costumer that are already in the social media environment (Sharmila et al., 2018).

Many of the new social media such as forums and blogs that have emerged on the web have become important platforms for individuals to exchange information (Chau \& Xu, 2012). These tools make it possible to consolidate the available information to consumers to make their decision-making process more useful, before they make a purchasing decision, they can look for information online and consider the comments made by other consumers about the product or service. Several authors have found significant percentages of consumers who adopt this practice: Wu and Lin (2017), 36\%; Chiu and Shu (2017), approximately 15\%; and Constantinides and Holleschovsky (2016), $98 \%$.

Users gather social information during the process of purchasing a product on a social communication platform while also gathering other relevant data such as information about the quality of the product and the reputation of the seller (Bai et al., 2015). Many companies that consider the current market dynamics and the changes in the purchasing and consumption behavior of people, must have or develop a strategic approach to integrate social media in the general mix of marketing communications (Pachitanu et al., 2019).

The use of social media platforms has become an opportunity for companies to capture relevant information about consumers and shopping experiences, reducing access costs. However, companies should design mechanisms to process published information that does not reflect the reality of the shopping experience, which can occur because anonymous users can post comments too (Mei, Bagaas, \& Relling, 2018). Nevertheless, these platforms enable companies to segment and target their consumers in more personalized and effective ways, 
understand their behavior and the environment they live in, and motivate changes in marketing strategies focused on the opinions of these consumers, who sometimes reach a level of precision above expert marketing specialists (Nash, 2018). In this sense, social media have entered in the context of advertising as a mechanism to promote products, services and ideas; in response to the benefits that this type of platform presents as the comments and observations of other consumers (Kotnis et al., 2017; Lin \& Kim, 2016)the growth of this advertising platform has important implications for consumers, and advertisers alike. As little research is available on consumer response to sponsored advertising as an interactive technology innovation, the current study assesses the effects of user perceptions of privacy risk, intrusiveness concerns and utilities of sponsored advertising on consumer attitudes and purchase intent. Testing a model derived form the technology acceptance model (TAM. In fact, the distinct sources to generate and introduce product promotional messages take relevance on the credibility perception and consumer attitudes towards advertisements (Shareef et al., 2019).

The development of social media marketing systems for the promotion of products or services has become more relevant in several sectors, such as eco-tourism, where a system is developed to improve the interactions and desires of the people in the travel decisions (Tetiwat et al., 2019), in the arts field a social media technology helps to co-create perfomances in London International Festival of Theater (Miles, 2018), in the construction field, where the social media are used as a tool to compete with foreign enterprises (Adedeji et al., 2018) and finally, in the education field, social media are used to reach and recruit prospective students more effectively gaining insights into students' behaviors, needs, and attitudes (Xiong et al., 2018).

\section{Social commerce}

The trade that takes place through social media is called social commerce (SC) or social purchases (Chen et al., 2017). Social commerce is considered a subset of electronic commerce (Zhou et al., 2013) and has emerged thanks to the popularity of social media sites (Hajli \& Lin, 2014). The main contribution of social commerce is that consumers can interact and support one another throughout the purchasing process through the exchange of experiences and information about a product or service, such as information about past purchasing experiences (Featherman \& Hajli, 2015).

As a result, more and more people are making their purchases through different social platforms available for this type of commerce, substantially modifying the traditional behavior of product acquisition in brick-and-mortar establishments. Comments and experiences published in social networks have become highly usable mechanisms to generate experiences that directly influence purchase decisions. Transactions are evaluated without the intermediation of suppliers, thus creating a whole new purchasing ecosystem. These new contexts have be- 
come more present thanks to events organized to promote purchases through said platforms, offering different product alternatives, discounts, and promotions and even encouraging the impulsiveness of online consumers (compared to traditional ones). Social commerce has also generated an increase in the use of virtual payment methods, which have allowed the development of virtual financial systems (Hassan, Abdullah, \& Hassan, 2018). In that sense, social commerce has led businesses, especially retail companies, to design and strengthen different strategies to increase their sales through these platforms (Cho \& Son, 2019); for instance, encouraging interaction with consumers, making their websites easy to visit, generating previous shopping experiences (in which consumers receive detailed information about products in advance), and establishing consumer affinity with the brand.

Several factors are relevant antecedents of consumers' trust in online stores: brand knowledge, store reputation, perceived store size, and perceived store risk. Moreover, all of them are very important determinants of the intention to purchase online (Dutta \& Bhat, 2016); in this way, positive experiences encourage, significantly, future purchasing decisions (Triantafillidou \& Siomkos, 2014).

When consumers make purchases on electronic commerce platforms such as Amazon, eBay and Taobao, they often comment on the products / services after having used them, which helps other consumers to gather information about the product (Bai et al., 2015). However, it is difficult for consumers to rely on commercial platform reviews as long as they cannot make a real inspection of the product descriptions (Hayne et al., 2015). This problem can be mitigated by social media commercial platforms when the users of these networks are friends or indirect acquaintances; they share and communicate their experiences purchasing and using the product to obtain relatively true and accurate information about it (Bai et al., 2015).

\section{Technology Acceptance Model (TAM)}

The Technology Acceptance Model proposed by Davis (1989) is one of the most-used tools for predicting whether users will adopt a new technology. The acceptance of a technology is defined as the individual psychological state relating to the voluntary or foreseeable use of a particular technology (Ratna \& Mehra, 2015). The model is currently widely used for predicting the intention of users to accept new technologies in diverse sectors such as information technology, with an emphasis on the participation of online communities for learning or shopping (Di Pietro et al., 2012).

According to TAM, the intention to voluntarily accept and use a new information technology (IT) is determined by two beliefs: (a) Perceived Usefulness (PU) of using the new IT and (b) Perceived Ease of Use (PEOU) of the new IT. PU is a measurement of an individual's 
subjective evaluation of the usefulness of the new IT in a context related to the specific task, while PEOU is an indicator of the cognitive effort required to learn and use the new IT (Teo et al., 2015).

According to Elwalda et al. (2016), TAM suggests that Perceived Usefulness and Perceived Ease of Use are the main determinants of system use and adoption of information. Perceived Usefulness is defined as "the degree to which a person believes that using a particular system would enhance his or herjob performance" while Perceived Ease of Use is defined as "the degree to which a person believes that using a particular system would be free from effort "(Davis, 1989, p. 320).

Based in the described definitions, this article refers to Perceived Usefulness as the degree to which one believes that if a marketing manager perceives usefulness when make social media marketing, this will positively affect its behavioral intention to adopt this marketing way, whether directly or indirectly, through Attitude toward adoption, thereby making it an excellent marketing tool for companies. This is summarized in the following hypotheses:

H1. Perceived Usefulness of social media marketing has a positive impact on behavioral intention to adopt this marketing way among marketing managers.

H2. Perceived Usefulness has a positive impact on Attitude toward social media marketing adoption.

H3. Attitude toward social media marketing adoption has a direct and positive influence on behavioral intention to adopt this marketing way among marketing managers.

For the purposes of this study, Perceived Ease of Use refers to the degree to which it is thought that a marketing manager will, as a consequence of this belief, have both a more favorable Attitude toward social media marketing adoption and a greater Perceived Usefulness about. Therefore:

H4. Perceived Ease of Use has a positive effect on marketing managers' Attitude toward social media marketing adoption.

H5. Perceived Ease of Use of social media marketing has a positive effect on their Perceived Usefulness.

In addition to providing an analytical framework for determining the relationship between Perceived Ease of Use and Perceived Usefulness, TAM also considers other external variables (Jin, 2014). Elwalda et al. (2016), Ahmad and Khalid (2017) consider trust to be one of them.

Some authors stress the importance of trust in virtual environments. For example, McKnight and Chervany (2002); Jarvenpaa, Cantu, and Lim (2017); and Duradoni et al. (2018) define trust in work environments as a psychological state in which an individual or group participates. Not only an individual but an organization, team, institution, or community can 
be associated with a state of trust. However, this definition assumes a human-to-human context and, as a result, the weak trust derived (at least partially) from the impersonal nature of online relationships is a matter of concern. Aspects related to whether trust matters, the forms it takes, and how it works in virtual environments have serious consequences for online commerce environments. The dynamics of fairness, trust, and social influence in virtual environments have received increasing attention. In fact, these three constructs seem to play a fundamental role in a plethora of virtual social interactions. Trust is not only between the customers and the pages through which they make their purchases, but also between the customer and the technological infrastructure. In other words, institutional trust is as important as interpersonal trust in the online environment. Meanwhile, Kollat and Farache (2017), argue that creating emotional bonds increase consumer confidence.

According to Butt (2016)online shopping is still in infancy in South Asia despite tremendous growth potential with its burgeoning population. The purpose of this research is to examine the behavioral acceptance of consumers towards online shopping using technology acceptance model (TAM, trust is a fundamental factor in making purchases in general, and particularly in the online context. In this regard, Liébana-Cabanillas et al. (2017)especially among young generations. The purpose of this paper is to determine the key factors that influence consumerslu2019 adoption of mobile commerce. The extended model incorporates basic TAM predictors, such as perceived usefulness and perceived ease of use, but also several external variables, such as trust, mobility, customization and customer involvement. Data was collected from 224 m-commerce consumers. First, structural equation modeling (SEM suggested that confidence as an importance factor in addition to those included in the TAM model. In their investigation they reported evidence that, trust in such context is related to security and accuracy in payments, management of personal information and experiences and products' personalization.

Similar to how Gefen et al. (2003) demonstrated in his study that Trust had a positive impact on the Perceived Usefulness of a website, the objective of this study was to determine whether or not Trust affects either the Perceived Usefulness or the Perceived Ease of Use of social media marketing. To this end, the following hypotheses were made:

H6. Perceived Ease of Use of social media marketing has a positive effect on their Perceived Usefulness.

H7. Perceived Ease of Use of social media marketing has a positive effect on their Perceived Usefulness.

The proposed model with the objective of identifying factors, and possible relationships between them, in the adoption of social media marketing for retail companies is presented in Fig. 1. 


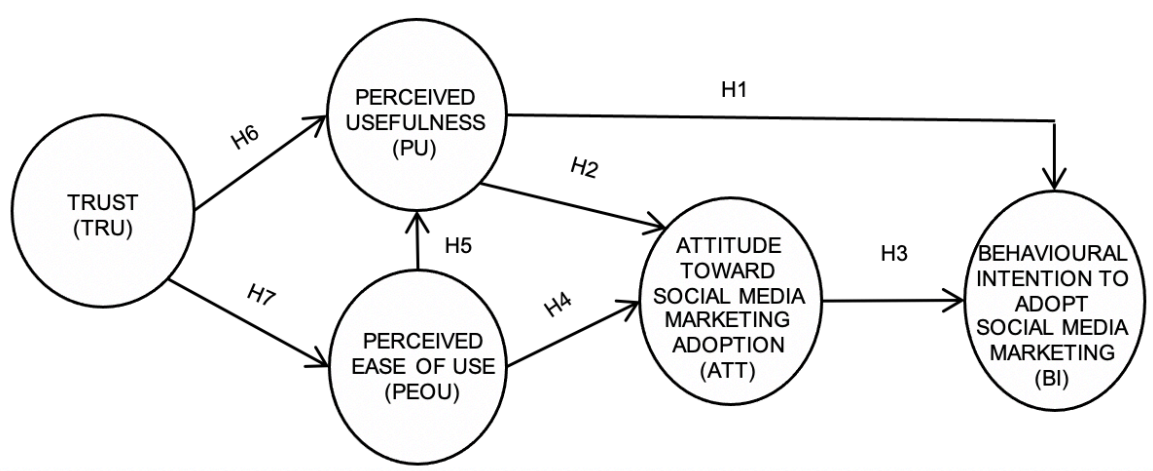

Figure. 1. Proposed research model.

Source: Author's own

\section{Methodology}

A field-based, cross-cutting, quantitative exploratory methodology was applied to identify the factors that influence the adoption of social media marketing for retail companies, based on the Technology Acceptance Model (TAM) proposed by Davis (1989) and using two variables: Perceived Usefulness and Perceived Ease of Use.

To collect data, 458 self-administered questionnaires were applied for the months of March through November in 2017 to marketing managers in the retail sector in Medellín (Colombia), selected based on a non-probabilistic sampling by criteria. It was necessary to reject $37(8.1 \%)$ of the questionnaires applied as they were not properly filled out, resulting in a total of 421 . The tool that was used included dichotomous questions and five-point Likert scale questions (strongly agree, agree, neither agree nor disagree, disagree or strongly disagree) designed to measure each of the specified TAM factors.

Behavioural intention was measured through the question: "What does your company use social media for? With five answer options (5 items): To make sales / To attract and retain customers / To promote products / To resolve doubts and complaints of customers / database (adapted from Reuter, Ludwig, Kaufhold, \& Spielhofer, 2016). To measure Perceived Usefulness 6 items were used. An example of item is "Using social media is useful for companies" (adapted from Venkatesh, 2000). To measure attitude towards social media marketing adoption 3 items were used. One of the items is "Social media are a useful tool for sharing information between companies and their current and potential consumers" (adapted from Reuter, Ludwig, Kaufhold, \& Spielhofer, 2016). Regarding the construct Trust, 4 items were considered. "It is safe providing sensitive information in social media" is an example 
of item (adapted from Taylor, Lewin, \& Strutton, 2011). Perceived ease of use was measured through 3 items. An example of item is "Learning to use social media is easy" (adapted from Lane \& Coleman, 2012).

With the objective of evaluating the fit of the proposed model to the collected data, Confirmatory Factor Analysis (CFA) was used to verify the model constructs and the validity of used variables (Diniz \& Vale, 2016), while the methodology of Structural Equation Modeling (SEM) was used as a comprehensive statistic to check hypotheses regarding the relationships between the proposed model's observed and latent variables. A significant advantage of this methodology lies in its ability to estimate a complete model that shows the statistical relationship between latent and observable variables (Teo \& Milutinovic, 2015).

\section{Analysis of results}

Agag and El-Masry (2016) indicate that the measurement model must be evaluated prior to the evaluation of the structural model. For that purpose, the reliability of the measurement items should be confirmed, and convergent and discriminant validations should be carried out (Hair et al., 2014). As a result, the internal consistency of the measurement items can be analyzed.

\section{Reliability and validity of the measurement items}

The reliability of the internal consistency of the tool used is estimated using Cronbach's alpha as it is a reliability tool in which it is assumed that items (Likert-type scale) measure the same construct and are highly correlated (Welch \& Comer, 2006). If the value of Cronbach's alpha is closer to 1 , then the internal consistency of the items is greater. As illustrated in Table 1, the measurement tool shows high reliability of the internal consistency of the measurement scale, as the Cronbach alphas for each construct surpass the cut-off value of 0.7 (Hair et al., 2014).

In order to evaluate the validity of the measurement items, both convergent and discriminant validity must be verified. Tarhini (2015) suggests that convergent validity as a grade of relationship between construcs. Authors such as Hair et al. (2014) indicate that this can be satisfied if the factor loadings of the items are 0.5 or higher, and ideally .7 or higher for all of the constructs. In accordance with these guidelines, items PU3 and PEOU4 were eliminated. The standardized factor loadings of the remaining items are presented in Table 2 where both criteria are satisfied, thereby indicating convergent validity. 
Table 1

Reliability Index-Cronbach's alpha

\begin{tabular}{lc}
\hline Factor & Cronbach's alpha \\
\hline Behavioural intention to adopt social media marketing & 0.817 \\
Perceived Usefulness & 0.824 \\
Attitude toward social media marketing adoption & 0.752 \\
Trust & 0.858 \\
Perceived ease of use & 0.878 \\
\hline
\end{tabular}

Source: Author's own with the support of SPSS statistics software.

Table 2

Initial convergent validity of standardized factor loadings

\begin{tabular}{|c|c|c|c|}
\hline Construct & Item & $\begin{array}{l}\text { Standardized factor } \\
\text { loadings }\end{array}$ & $\begin{array}{c}\text { Average of standardized factor } \\
\text { loadings }\end{array}$ \\
\hline \multirow{5}{*}{$\begin{array}{l}\text { Behavioural intention to } \\
\text { adopt social media mar- } \\
\text { keting }\end{array}$} & BI 1 & 0.798 & \multirow{5}{*}{0.771} \\
\hline & BI 2 & 0.817 & \\
\hline & BI 3 & 0.793 & \\
\hline & BI 4 & 0.756 & \\
\hline & BI 5 & 0.691 & \\
\hline \multirow{5}{*}{ Perceived Usefulness } & PU 1 & 0.774 & \multirow{5}{*}{0.762} \\
\hline & PU 2 & 0.784 & \\
\hline & PU 4 & 0.785 & \\
\hline & PU 5 & 0.707 & \\
\hline & PU 6 & 0.760 & \\
\hline \multirow{3}{*}{$\begin{array}{l}\text { Attitude toward social media } \\
\text { marketing adoption }\end{array}$} & ATT 1 & 0.81 & \multirow{3}{*}{0.82} \\
\hline & ATT 2 & 0.83 & \\
\hline & ATT 3 & 0.84 & \\
\hline \multirow{3}{*}{ Trust } & TRU 1 & 0.832 & \multirow{3}{*}{0.832} \\
\hline & TRU 2 & 0.855 & \\
\hline & TRU 3 & 0.809 & \\
\hline \multirow{3}{*}{ Perceived ease of use } & PEOU 1 & 0.861 & \multirow{3}{*}{0.87} \\
\hline & PEOU 2 & 0.872 & \\
\hline & PEOU 3 & 0.877 & \\
\hline
\end{tabular}

Source: Author's own with the support of SPSS statistics software. 
Discriminant validity, on the other hand, is the degree to which two concepts that are conceptually similar differ (Hair et al., 2014). In this study, analysis of discriminant validity was carried out by verifying that the trust interval in the estimation of the correlation between each pair of factors did not contain the value of 1 (Anderson \& Gerbing, 1988). Table 3 shows that all of the cases fulfil this criterion.

Table 3

Discriminant validity of the measurement model

\begin{tabular}{cccccc}
\hline & BI & PU & ATT & TRU & PEOU \\
\hline BI & $\ldots$ & & & & \\
PU & {$[0.349 ; 0,524]$} & $\ldots$ & & & \\
ATT & {$[0.318 ; 0,497]$} & {$[0.503 ; 0,641]$} & $\ldots$ & & \\
TRU & {$[0.149 ; 0,352]$} & {$[0.197 ; 0,383]$} & {$[0.247 ; 0,418]$} & $\ldots$ & \\
PEOU & {$[0.222 ; 0,413]$} & {$[0.208 ; 0,397]$} & {$[0.248 ; 0,429]$} & {$[0.306 ; 0,475]$} & $\ldots$ \\
\hline
\end{tabular}

Source: Author's own with the support of SPSS statistics software.

The favorable results of the reliability and validity analyses verify the measurement model, giving rise to the evaluation of the structural model designed to identify the factors that directly or indirectly influence the use of social media as a marketing tool by retail companies.

\section{Contrast of hypotheses}

Following verification of the internal consistency of the model and the degree of association between the observed variables and the different constructs, the Confirmatory Factor Analysis technique was applied. According to Kline (2015), RMSEA and the chi-squared test ( are used to evaluate the fit of the model. A RMSEA 0.06 and a indicate a good fit (Hu \& Bentler, 1999). Initially, a RMSEA of 0.07 and a 382.174 / $142<3$ were obtained. As such, some correlations between the residuals of the variables associated with the constructs of Perceived Usefulness and Use of Social Media were included. As a result, the RMSEA went down to 0.06 , thereby achieving a good fit.

Other indices of fit used in this study to verify the goodness of fit of the model are the CFI, TLI and SRMR indices. According to Hair et al. (2014), the values of the CFI and TLI indices vary from 0 to 1 and values above 0.9 indicate a good fit. As for the SRMR index, Hu and Bentler (1999) establish that the cut-off point is 0.08 , meaning that values below these points are necessary in order to conclude that there is a good fit. 
Once a good fit was obtained with regard to the measurement model (Table 4), the following step was the verification of the hypotheses (Fig. 2) through analysis of the model of structural equations, for which the SEM function of the R software (The R Core Team, 2016) Lavaan package (Rosseel, 2012) was used.

Table 4

Measurements of goodness of fit of the model

\begin{tabular}{ccccc}
\hline Index & Measured value & Cut-off & Source: & Decision \\
\hline CFI & 0.926 & $<0.9$ & Hair et al. (2006) & Acceptable \\
TLI & 0.909 & $<0.9$ & Hair et al. (2006) & Acceptable \\
SRMR & 0.053 & $<0.08$ & Hu and Bentler (1999) & Acceptable \\
\hline
\end{tabular}

Source: Author's own

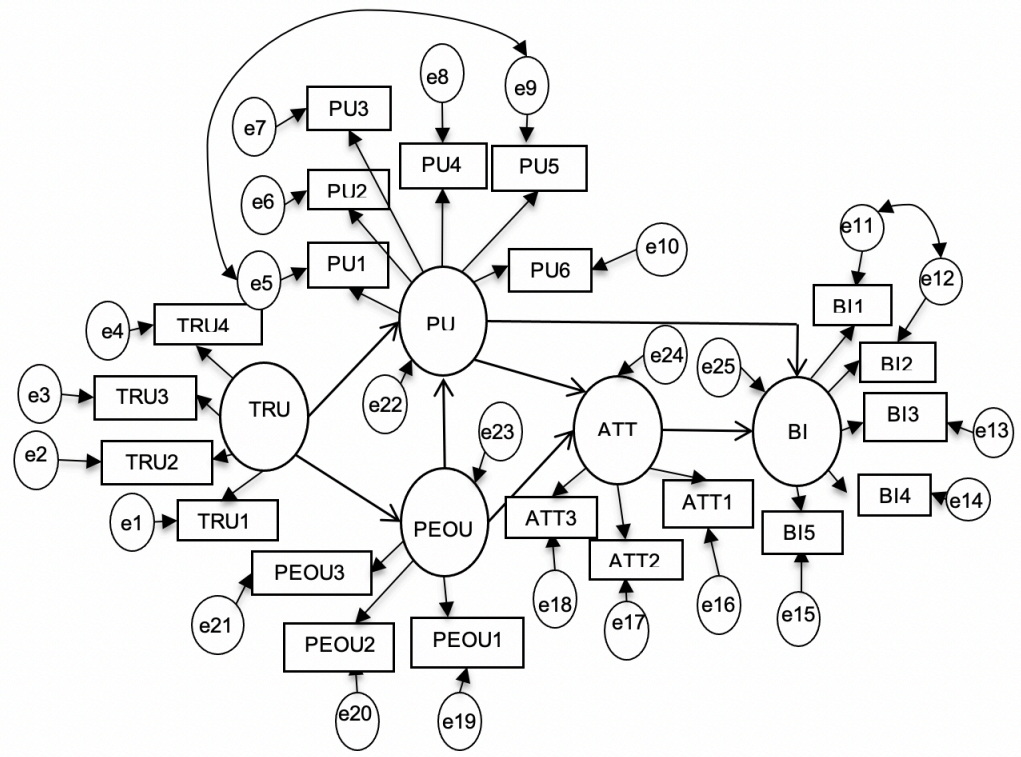

Figure. 2. Model of structural equations.

Source: Author's own

The values for the coefficients and the p-values for each of the regression equations considered in the structural model are presented in Figure 3. Of the seven hypotheses, only one of 
them is not supported by the data (H5), meaning that it is not possible to affirm that Perceived Ease of Use of social media marketing has a positive effect on its Perceived Usefulness. On the other hand, the Behavioural intention to adopt social media marketing is promoted by both Perceived Usefulness and by Attitude toward its adoption, according to the support found for hypotheses $\mathrm{H} 1$ and $\mathrm{H} 3$, respectively. In addition, trust directly and positively affects factors like Perceived Usefulness and Perceived Ease of Use (hypotheses 6 and 7). Lastly, Attitude toward social media marketing adoption is influenced by factors like Perceived Usefulness and Perceived Ease of Use (hypotheses 2 and 4).

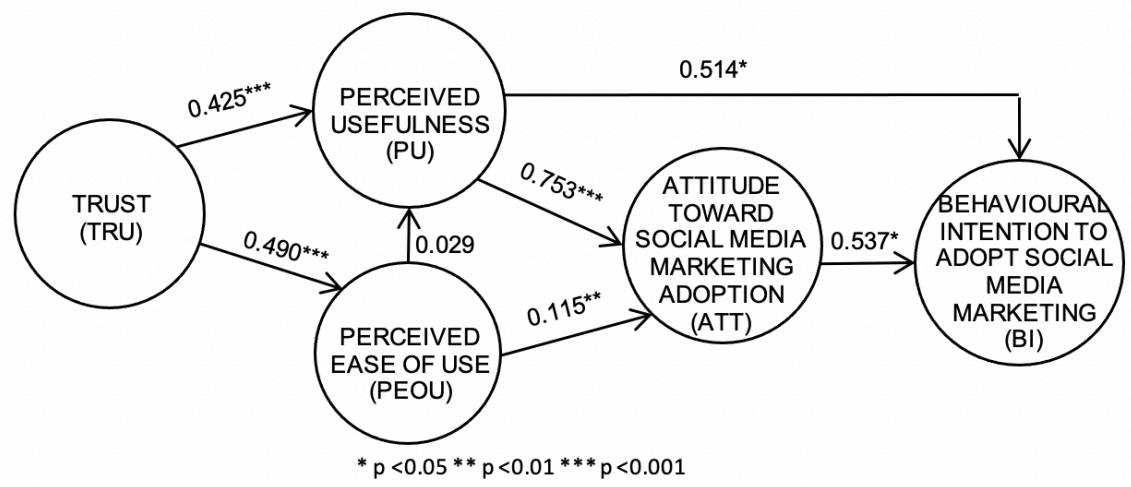

Figure. 3. Results of the hypothesis tests.

Source: Author's own

\section{Discussion}

The technological factor has become one of the challenges that businesses have had to take on during the past years, as ICTs are a tool that plays a crucial role in the modern economy with numerous implications for economic and social development as mechanisms that facilitates the management and control of information within a business (Apulu, 2012). McCann and Barlow (2015) have explained the use of information and the development of social media as tools that allow users to communicate in real time and that facilitates the exchange of information among individuals. This has an influence on the decision-making process for businesses.

The results of this study ratify the findings of Willis (2008) with regards to the rejection of hypothesis H5, as the Perceived Ease of Use does not have an effect on its Perceived Usefulness; that is, based on the sample data, the usefulness of social networks does not depend 
on the perception of how easy or difficult it is to use them. Nevertheless, Willis (2008) found an opposite effect to that proposed in the present study: according to respondents, the more difficult to use, the greater the usefulness.

Like other research carried out by various authors (Butt, 2016; Elwalda et al., 2016; Hajli et al., 2017; Oliveira et al., 2017), this study reaffirms the importance of trust when it comes to online environments. In this sense, Butt (2016), suggested some elements related to trust in the online context such as adequate controls of privacy, computer security and risk reduction; in the same way, Il-Hyun and Zamrudi (2018) found elements associated to trust with some psychological factors such as the search for a sense of affiliation and belonging to the social network through which the transaction is made, establish and maintain relationships with the members of this social network and be able to share experiences with them. Hajli et al. (2017) and Il-Hyun and Zamrudi (2018) highlighted that on sites where buyers can leave comments and reviews regarding their experiences with the product, this becomes a dominant factor in encouraging a purchase. In this respect Ha, Kankanhalli, Kishan and Huang (2016) suggest that trust can increase with product verification processes as this can reduce risks of quality, security and privacy of information. Similarly, Reyes-Mercado and Rajagopal (2015) and Elwalda et al. (2016) found that Trust has such a strong influence on Perceived Ease of Use and Perceived Usefulness that it could even lead to increased purchasing on these kinds of platforms (SNS) when the perception of it is significantly positive.

It should also be highlighted that according to the results of this study, Perceived Usefulness has a significant positive influence on the Attitude toward social media marketing adoption ( coefficient of 0.753 , the highest of all of those calculated), explained as the usefulness marketing managers experience when using social media marketing. Important studies that have been backed up by TAM have identified this same relationship to be highly relevant (Ahmed and Ahmad, 2016; Elwalda et al., 2016; Assimakopoulos et al., 2017). Specifically, Ramadani et al. (2014) identified in their studies that Perceived Usefulness has a strong influence on the use of social media in the context of marketing. Given this, Shang and Wu (2017) highlight the need to develop differentiated campaigns for different target populations of a marketing strategy, since perceptions of usefulness vary according to cultural and generational factors; these strategies must consider different elements to guarantee their success. In this sense, Adamu, Papaioannou and Komodromos (2018), identified as relevant factors that intervene in the perception of the Utility of social media marketing the access to Internet services, skills of use it, purchase's previous experience and trust, confirming the results found in our study. 


\section{Conclusions}

When considering this study's objective of identifying factors that promote the adoption of social media marketing, it is important to highlight not only the evaluation of the fit of the model to the data but also the significance of this, as it verified the relevance of the elements proposed by the Technology Acceptance Model. In addition, this study made it possible to reaffirm the positive influence of Trust on the constructs of Perceived Usefulness and Perceived Ease of Use, which promote the adoption of Social Media marketing ; associated with elements such as pricing, privacy violations, transmission of inaccurate information, unauthorized transaction tracking, and unauthorized use of financial information. In this sense, there are authors such as Awad and Ragowsky (2008) who found that Trust has such an impact on the aforementioned constructs, which could even lead to increased purchases through such platforms (SNS), when their perception is significantly positive.

From the results it was possible to identify that the Attitude is highly influenced by the Perceived Usefulness, which implies that companies have to design differentiated campaigns for each type of clients, while the perceptions of usefulness vary according to different features of them.

Given the above, companies could benefit from the adoption of social media marketing. Recommendations include training programs for employees as a way to generate the knowledge, skills and techniques required to operate in the field of information technology, as well as investment in the latest technology, competent consulting and investment in modern information technology infrastructure that guarantees efficient business processes.

This study confirms once more that the Technology Acceptance Model constituting an important tool for examining and identifying factors, variables and relationships that inhibit or motivate the process of introducing new technologies, and although the measurements presented in the original study by Davis (1989) apply to employees' acceptance of a particular software, they have also been validated for different types of users and systems (Moreno \& Molina, 2012) with the aim of predicting intentions to accept new technologies in diverse fields such as information technology, education, tourism and others. This study demonstrates that TAM allows for an examination of how different factors affect company decisions to adopt or not to adopt social media for use in their areas and processes, such as those related to marketing decisions.

Although the research confirms a series of hypotheses related to factors that encourage the adoption of social media marketing in this era characterized by technological advances, its scope does not go beyond the retail sector. Therefore, research that validates the proposed model and variables as well as the relationships identified between them is desirable for other sectors and social and economic contexts. Adamu, Papaioannou and Komodromos (2018), 
proposed as an element of importance to increase research in social media marketing including different populations to students and be able to focus more on decision makers in this field, as well as to include different techniques of quantitative analysis to the data. In this sense, our study makes a contribution to this field of research based on the population analyzed and how to perform the analysis of the data. On the other hand, the importance of this study is highlighted to the extent that the retail sector, (specifically marketing managers), now has a tool (the proposed model) that will allow them to design social media marketing strategies in a structured way and with greater possibility of increasing their participation in the market, similar to that found by Kumar, Vikram, Mirchandani and Shah (2013) for the social media marketers sector.

In addition, a suggestion for future work would be to strengthen the proposal presented here by fusing its components with factors from different models such as the expectation-confirmation model (ECM), putting special emphasis on perceived value due to its direct link to satisfaction and the amounts that online clients are willing to pay for a product.

\section{References}

Adamu, M.A., Papaioannou, T., \& Komodromos, M. (2018). Influence of online retailers' social media marketing strategies on students' perceptions towards e-shopping: a qualitative study. International Journal of Technology Enhanced Learning, 10 (3), 218. https: //doi.org/10.1504/ijtel.2018.10010201

Adedeji, A., Rapheal, O., \& Opeyemi, O. (2018). An analysis of social media marketing of indigenous construction companies in nigeria: A tool for sustainable growth. International Journal of Construction Supply Chain Management, 8 (2), 60-72. Available at http://eprints.covenantuniversity.edu.ng/12407/\#.X4XcJdAzaUk [Accesed: 20-03-2019]

Agag, G., \& El-Masry, AA. (2016). Understanding the determinnts of hotel booking intentions and moderating role of habit. International Journal of Hospitality Management, 54, 52-67. https://doi.org/10.1016/j. ijhm.2016.01.007

Ahmad, S.Z., \& Khalid, K. (2017). The adoption of M-government services from the user's perspectives: Empirical evidence from the United Arab Emirates. International Journal of Information Management, 37, 367-379. https://doi.org/10.1016/j.ijinfomgt.2017.03.008

Ahmed, Y.A., \& Ahmad, M.N. (2016). Towards Exploring Factors That Influence Social Media-Based Knowledge Sharing Intentions in Disaster Management nor Hidayati Zakaria. Journal of Theoretical and Applied Information Technology, 3088 (3), 487-498. Available at: www.jatit.org [Accessed: 25-08-2018]

Anderson, J.C., \& Gerbing, D. (1988). Structural equation modeling in practice: A review and recommended twostep approach. Psychological bulletin, 103 (3), 411. https://doi.org/10.1037/0033-2909.103.3.411

Apulu, I. (2012). Developing a Framework for Successful Adoption and Effective Utilization of ICT by SMEs in Developing Countries: A Case Study of Nigeria. Thesis, (Ph.D). University of Wolverhampton. Available at: https://wlv.openrepository.com/handle/2436/249899 [Accessed: 5-02-2018] 
Assimakopoulos, C., Antoniadis, I., Kayas, O.G., \& Dvizac, D. (2017). Effective social media marketing strategy: Facebook as an opportunity for universities, International Journal of Retail and Distribution Management, 45 (5), 532-549. https://doi.org/10.1108/IJRDM-11-2016-0211

Awad, N.F., \& Ragowsky, A. (2008). Establishing trust in electronic commerce through online word of mouth: an examination across genders. Journal of Management Information Systems, 24 (4), 101-121. http://dx.doi. org/10.2753/ MIS0742-1222240404

Bai, Y., Yao, Z., \& Dou, Y. (2015). Effect of social commerce factors on user purchase behavior: An empirical investigation from renren.com. International Journal of Information Management, 35(5), 538-550. https://doi. org/10.1016/j.ijinfomgt.2015.04.011

Butt, I. (2016). Using Technology Acceptance Model to study adoption of online shopping in an emerging economy. Journal of Internet Banking and Commerce, 21 (2). Available at: https://www.icommercecentral.com/ open-access/using-technology-acceptance-model-to-study-adoption-of-online-shopping-in-an-emerging-economy.php?aid=78327 [Accessed: 17-10-2018]

Chau, M., \& Xu, J. (2012). Business intelligence in blogs: Understanding consumer interactions and communities. MIS quarterly, 36 (4). 1189-1216. https://doi.org/10.2307/41703504

Chen, A., Lu, Y., \& Wang, B. (2017). Customers' purchase decision-making process in social commerce: A social learning perspective. International Journal of Information Management, 37, 627-638. https://doi. org/10.1016/j.ijinfomgt.2017.05.001

Chiu, C., \& Shu, C. H. (2017). Monthly car sales prediction using Internet Word-of-Mouth (eWOM). Proceedings - 2017 IEEE International Conference on INnovations in Intelligent SysTems and Applications, INISTA 2017, (2003), 345-348. https://doi.org/10.1109/INISTA.2017.8001183

Cho, E., \& Son, J. (2019). The effect of social connectedness on consumer adoption of social commerce in apparel shopping. Fashion and Textiles, 6(14). https://doi.org/10.1186/s40691-019-0171-7

Chun, J., \& Lee, M. (2016). Increasing individuals' involvement and WOM intention on Social Networking Sites: Content matters! Computers in Human Behavior, 60, 223-232. https://doi.org/10.1016/j.chb.2016.02.069

Constantinides, E., \& Holleschovsky, N.I. (2016). Impact of online product reviews on purchasing decisions. WEBIST 2016 - Proceedings of the 12th International Conference on Web Information Systems and Technologies, 1(Webist), 271-278. https://doi.org/10.5220/0005861002710278

Davis, F. (1989). Perceived usefulness, perceived ease of use, and user acceptance of information technology. MIS Quarterly, 13, 319-340. https://doi.org/10.2307/249008

Dehghani, M., \& Tumer, M. (2015). A research on effectiveness of Facebook advertising on enhancing purchase intention of consumers. Computers in Human Behavior, 49, 597-600. https://doi.org/10.1016/j.chb.2015.03.051

Diniz, F., \& Vale L.H. (2016). Entrepreneurship and Social Innovation in Training and Human Capital Development: The Case of the Bank Palmas. Economy of Region, 12 (3), 865-874. https://doi.org/10.17059/2016-3-21

Di Pietro, L., Di Virgilio, F., \& Swamp, E. (2012). Social network for the choice of tourist destination: attitude and behavioural intentional. Journal of Hospitality and Tourism Technology, 3 (1), 60-76. https://doi. org/10.1108/17579881211206543

Duradoni, M., Paolucci, M., Bagnoli, F., \& Guazzini, A. (2018). Fairness and trust in virtual environments: the effects of reputation. Future Internet, 10(6), 50. https://doi.org/10.3390/fi10060050

Dutta, N., \& Bhat, A. (2016). Exploring the effect of store characteristics and interpersonal trust on purchase intention in the context of online social media marketing. Journal of Internet Commerce, 15(3), 239-273. https://doi. org/10.1080/15332861.2016.1191053

Elwalda, A., Lu, K., \& Ali, M. (2016). Perceived derived attributes of online customer reviews. Computers in Human Behavior, 56, 306-319. https://doi.org/10.1016/j.chb.2015.11.051

Featherman, M.S., \& Hajli, N. (2015). Self-Service Technologies and e-Services Risks in Social Commerce Era. Journal of Business Ethics, 1-19. https://doi.org/10.1007/s10551-015-2614-4 
Gefen, D., \& Straub, D. (2000). The relative importance of perceived ease-of-use in IS adoption: A study of e-Commerce adoption. Journal of the association for Information Systems, 1 (8), 1-30. https://doi.org/10.17705/ 1jais.00008

Gefen, D., Karahanna, E., \& Straub, D. (2003). Trust and TAM in online shopping: an integrated model. MIS quarterly, 27 (1), 51-90. https://doi.org/10.2307/30036519

Ha, S., Kankanhalli, A., Kishan, S. J., \& Huang, K.-W. (2016). Does social media marketing really work for online SMEs?: An empirical study. 37th International Conference on Information Systems, ICIS, (p. 1-21). Dublin, Ireland. Available at: https://www.scopus.com/record/display.uri?eid=2-s2.0-85019400720\&origin=inward\&txGid=f1b4101a39e90da77347b3432aab1a6a [Accessed: 15-07-2018]

Hair, J.F., Black, W.C., Babin, B.J., \& Anderson, R.E. (2014). Multivariate Data Analysis (7 ${ }^{\text {th }}$ Ed.), Edinburgh Gate: Pearson Education Limited.

Hajli, N., \& Lin, X. (2014). Exploring the security of information sharing on social networking sites: The role of perceived control of information. Journal of Business Ethics, 1-13. https://doi.org/10.1007/s10551-014-2346-X

Hajli, N., Sims, J., Zadeh, A.H., \& Richard, M.O. (2017). A social commerce investigation of the role of trust in a social networking site on purchase intentions. Journal of Business Research, 71, 133-141. https://doi. org/10.1016/j.jbusres.2016.10.004

Hamilton, M., Kaltcheva, V.D., \& Rohm, A.J. (2016). Hashtags and handshakes: consumer motives and platform use in brand-consumer interactions. Journal of Consumer Marketing, 33 (2), 135-144. https://doi.org/10.1108/ JCM-04-2015-1398

Hassan, H. Bin, Abdullah, S., \& Hassan, J. (2018). A Conceptual Framework on Social Platform, Compulsive Buying and Responsible Use towards Credit Card Debt among Young Adult. The Journal of Social Sciences Research, 4, 30-35. https://doi.org/10.32861/jssr.spi4.30.35

Hayne, S.C., Wang, H., \& Wang, L. (2015). Modeling Reputation as a Time-Series: Evaluating the Risk of Purchase Decisions on eBay. Decision Sciences, 46, 1077-1107. https://doi.org/10.1111/deci.12156

Hu, L., \& Bentler, P. (1999). Cutoff criteria for fit indexes in covariance structure analysis: Conventional criteria versus new alternatives. Structural equation modeling: a multidisciplinary journal, 6 (1), 1-55. https://doi. org/10.1080/10705519909540118

Il-Hyun, B., \& Zamrudi, M. F. (2018). Challenge of Social Media Marketing \& Effective Strategies To Engage More Customers: Selected Retailer Case Study. International Journal of Business and Society, 19(3), 851-869. Available at: http://www.ijbs.unimas.my/images/repository/pdf/Vol19-no3-paper18.pdf [Accessed: 5-01-2019]

Jarvenpaa, S. J., Cantu, C., \& Lim, S. Y. (2017). Trust in virtual online environments. The Wiley Blackwell handbook of the psychology of the internet at work. Chichester: Wiley-Blackwell, 103-130. https://doi. org/10.1002/9781119256151.ch6

Jin, C. (2014). Adoption of e-book among college students: The perspective of an integrated TAM. Computers in Human Behavior, 41, 471-477. https://doi.org/10.1016/j.chb.2014.09.056

Kemp, S. (2019). Global Digital Reports. Available at: https://datareportal.com/reports/digital-2019-bolivia?rq=bolivia [Accessed: 20-02-2019]

Kline, R.B. (2015). Principles and practice of structural equation modeling (3rd Ed.). Guilford publications.

Kollat, J., \& Farache, F. (2017). Achieving consumer trust on Twitter via CSR communication. Journal of Consumer Marketing, 34 (6), 505-514. https://doi.org/10.1108/JCM-03-2017-2127

Kotnis, B., Sunny, A., \& Kuri, J. (2017). Incentivized Campaigning in Social Networks. IEEE/ACM Transactions on Networking, 1-14. https://doi.org/10.1109/TNET.2016.2645281

Kumar, V., Vikram, B., Mirchandani, R., \& Shah, M. (2013). Practice Prize Winner-Creating a Measurable Social Media Marketing Strategy: Increasing the Value and ROI of Intangibles and Tangibles for Hokey Pokey. Marketing Science, 32(2), 194-212. https://doi.org/10.1287/mksc.1120.0768

Kumar, S., Ramachandran, T., \& Panboli, S. (2015). Product Recommendations over Facebook: The Roles of Influencing Factors to Induce Online Shopping. Asian Social Science, 11(2), 202. https://doi.org/10.5539/ass. v11n2p202 
Lane, M., \& Coleman, P. (2012). Technology ease of use through social networking media. Journal of Technology Research, 3(1). Available at: http://www.aabri.com/manuscripts/11758.pdf [Accessed: 4-11-2017]

Li, J., Ji, H., Qi, L., Li, M., \& Wang, D. (2015). Empirical Study on Influence Factors of Adaption Intention of Online Customized Marketing System in China. International Journal of Multimedia and Ubiquitous Engineering, 10(6), 365-378. https://doi.org/10.14257/ijmue.2015.10.6.35

Liébana-Cabanillas, F., Marinkovi, V., \& Kalini, Z. (2017). A SEM-neural network approach for predicting antecedents of m-commerce acceptance. International Journal of Information Management, 37, 14-24. https:// doi.org/10.1016/j.ijinfomgt.2016.10.008

Lin, C.A., \& Kim, T. (2016). Predicting user response to sponsored advertising on social media via the technology acceptance model. Computers in Human Behavior, 64, 710-718. https://doi.org/10.1016/j.chb.2016.07.027

McCann, M., \& Barlow, A. (2015). Use and measurement of social media for SMEs. Journal of Small Business and Enterprise Development, 22 (2), 273-287. https://doi.org/10.1108/JSBED-08-2012-0096

Mcknight, D., \& Chervany, N. (2002). What trust means in e-commerce customer relationships: an interdisciplinary conceptual typology. International Journal of Electronic Commerce, 6 (2), 35-59. https://doi.org/10.1080/108 64415.2001.11044235

Mei, X. Y., Bagaas, I. K., \& Relling, E. K. L. (2018). Customer complaint behaviour (CCB) in the retail sector: why do customers voice their complaints on Facebook? The International Review of Retail, Distribution and Consumer Research, 29(1), 63-78. https://doi.org/10.1080/09593969.2018.1556179

Miles, S. (2018). Do we have LIFT-off? social media marketing and digital performance at a british arts festival. Journal of Arts Management Law and Society, 48(5), 305-320. https://doi.org/10.1080/10632921.2017.13663 79

Moreno, R., \& Molina, C. (2012). Public Marketing: Research, Applications and Strategy. ESIC Editorial.

Nash, J. (2018). Exploring how social media platforms influence fashion consumer decisions in the UK retail sector. Journal of Fashion Marketing and Management, 23(1), 82-103. https://doi.org/10.1108/JFMM-01-2018-0012

Nielsen (2012). State of the media: The social media report. Available at: http://blog.nielsen.com/nielsenwire/social/ [Accessed: 15-10-2016]

Oliveira, T., Alhinho, M., Rita, P., \& Dhillon, G. (2017). Modelling and testing consumer trust dimensions in e-commerce. Computers in Human Behavior, 71, 153-164. https://doi.org/10.1016/j.chb.2017.01.050

Pachitanu, A., Coescu, E.C., Florescu, M. S., Barbu, A.M., \& Orzan, M.C. (2019). A conceptual model of social media marketing strategy. In: 32nd International Business Information Management Association Conference, IBIMA 2018 - Vision 2020: Sustainable Economic Development and Application of Innovation Management from Regional Expansion to Global Growth, 2134-2143. Available at: https://ibima.org/accepted-paper/a-conceptual-model-of-social-media-marketing-strategy/ [Accessed: 5-02-2019]

Paiño, A. (2016). ¿Hacia dónde va el comercio electrónico en Colombia? Ploutos, 4(1), 17-24. Available at: https:// journal.ean.edu.co/index.php/plou/article/view/1371 [Accessed: 5-09-2018]

Ramadani, V., Demiri, A., \& Saiti-Demiri, S. (2014). Social media channels: The factors that influence the behavioural intention of customers. International Journal of Business and Globalisation, 12 (3) 297-314. https:// doi.org/10.1504/IJBG.2014.060214

Ratna, P., \& Mehra, S. (2015). Exploring the acceptance for e-learning using technology acceptance model among university students in India. International Journal of Process Management and Benchmarking, 5 (2), 194-210. https://doi.org/10.1504/IJPMB.2015.068667

Reuter, C., Ludwig, T., Kaufhold, M. A., \& Spielhofer, T. (2016). Emergency services - attitudes towards social media: A quantitative and qualitative survey across Europe. International Journal of Human-Computer Studies, 95, 96-111. https://doi.org/10.1016/j.ijhcs.2016.03.005

Reyes-Mercado, P., \& Rajagopal. (2015). Driving consumers towards online retailing technology: analyzing myths and realities. Journal of Transnational Management, 20 (3), 155-171. http://dx.doi.org/10.1080/15475778.20 15.1058688 
Rosseel, Y. (2012). Lavaan: An R package for structural equation modelling. Journal of Statistical Software, 48, 1-36. https://doi.org/10.18637/jss.v048.i02

Shang, D., \& Wu, W. (2017). Understanding mobile shopping consumers' continuance intention. Industrial Management and Data Systems, 117 (1), 213-227. https://doi.org/10.1108/IMDS-02-2016-0052

Shareef, M.A., Mukerji, B., Dwivedi, Y.K., Rana, N.P., \& Islam, R. (2019). Social media marketing: Comparative effect of advertisement sources. Journal of Retailing and Consumer Services, 46, 58-69. https://doi. org/10.1016/j.jretconser.2017.11.001

Sharmila, R., \& Kavitha, M. (2018). Effectiveness of social media marketing. Indian Journal of Public Health Research and Development, 9(11), 192-196. https://doi.org/10.5958/0976-5506.2018.01450.X

Shih-Chih, C., \& Chieh-Peng, L. (2019). Understanding the effect of social media marketing activities: The mediation of social identification, perceived value, and satisfaction. Technological Forecasting and Social Change, 140, 22-32. https://doi.org/10.1016/j.techfore.2018.11.025

Silva, H. (2011). Comportamiento de las superficies de retail en Colombia. Pensamiento y Gestión. 30 (junio). Available at: http://www.scielo.org.co/scielo.php?pid=S1657-62762011000100002\&script=sci_arttext\&tln$\mathrm{g}=\mathrm{pt}$ [Accessed: 5-10-2016]

Tarazana, G., Gómez, M., \& Montenegro, C. (2014). Buenas prácticas para implementación del comercio electrónico en pymes. Revista Visión Electrónica, 6(2). 31-45. Available at: https://revistas.udistrital.edu.co/index.php/ visele/article/view/3884/5499 [Accessed: 15-07-2018]

Tarhini, A., Hone, K., \& Liu, X. (2015). A cross-cultural examination of the impact of social, organisational and individual factors on educational technology acceptance between British and Lebanese university students. British Journal of Educational Technology, 46, 739-755. https://doi.org/10.1111/bjet.12169

Taylor, D.G., Lewin, J.E., \& Strutton, D. (2011). Friends, fans, and followers: do ads work on social media?: how gender and age shape receptivity. Journal of advertising research, 51(1), 258-275. https://doi.org/10.2501/ JAR-51-1-258-275

Teo, T., Fan, X., \& Du, J. (2015). Technology acceptance among pre-service teachers: Does gender matter? Australasian Journal of Educational Technology, 31, 235-251. https://doi.org/10.14742/ajet.1672

Teo, T., \& Milutinovic, V. (2015). Modelling the intention to use technology for teaching mathematics among pre-service teachers in Serbia. Australasian Journal of Educational Technology, 31, 363-380. https://doi. org/10.14742/ajet.1668

The R Core Team (2016). R: a language and environment for statistical computing, (3.3.1 ed). Vienna,Austria: R Foundation for Statistical Computing.

Tetiwat, O., Esichaikul, V., \& Esichaikul, R. (2019). Requirement Patterns Analysis and Design of Online Social Media Marketing for Promoting Eco-Tourism in Thailand. In: Unger H., Sodsee S., Meesad P. (eds) Recent Advances in Information and Communication Technology 2018. IC2IT 2018. Advances in Intelligent Systems and Computing, vol 769. Springer, Cham. https://doi.org/10.1007/978-3-319-93692-5_27

Triantafillidou, A., \& Siomkos, G. (2014). Consumption experience outcomes: satisfaction, nostalgia intensity, word-of-mouth communication and behavioural intentionals. Journal of Consumer Marketing, 31(6/7), 526540. https://doi.org/10.1108/JCM-05-2014-0982

Venkatesh, V. (2000). Determinants of perceived ease of use: integrating control, intrinsic motivation, and emotion into the technology acceptance model. Information Systems Research, 11 (4), 342-365. https://doi.org/10.1287/ isre.11.4.342.11872

Welch, S., \& Eat, J. (2006). Quantitative methods for public administration: Techniques and applications ( $3^{\text {rd }}$. ed.). Waveland Press.

Willis, T. (2008). An Evaluation of the Technology Acceptance Model as a Means of Understanding Online Social Networking Behavior, Thesis (Ph.D). University of South Florida. Available at: https://scholarcommons.usf. edu/cgi/viewcontent.cgi?article=1567\&context=etd [Accessed: 25-05-2017] 
Wu, T.Y., \& Lin, C.A. (2017). Predicting the effects of eWOM and online brand messaging: Source trust, bandwagon effect and innovation adoption factors. Telematics and Informatics, 34, 470-480. https://doi.org/10.1016/j. tele.2016.08.001

Xiong, L., Alsadoon, A., Maag, A., Prasad, P. W.C., Hoe, L.S., \& Elchouemi, A. (2018). Rise of social media marketing: A perspective on higher education. In: 13th International Conference on Computer Science and Education, ICCSE 2018, 704-709. https://doi.org/10.1109/ICCSE.2018.8468683

Zhou, L., Zhang, P., \& Zimmermann, H. (2013). Social commerce research: An integrated view. Electronic Commerce Research and Applications, 12 (2), 61-68. https://doi.org/10.1016/j.elerap.2013.02.003

Zuluaga, C. (2015). Éxito Group: As e-commerce gains strength in Colombia Zoom. Universidad EAN. 29-41. Available at: https://journal.universidadean.edu.co/index.php/plou/article/view/1490/1449 [Accessed: 16-082018] 